\title{
Correction to: Towards an integral perspective on leveraging sustainability transformations using the theory of modal aspects
}

\author{
S. Wigboldus ${ }^{1} \cdot$ H. Jochemsen ${ }^{2}$
}

Published online: 29 October 2020

(c) The Author(s) 2020

\section{Correction to: Sustainability Science https://doi.org/10.1007/s11625-020-00851-5}

In the original publication of the article, last three columns of Tables 6 and 7 were published incorrectly. The correct version of Tables 6 and 7 are provided below.

The original version was updated.

Open Access This article is licensed under a Creative Commons Attribution 4.0 International License, which permits use, sharing, adaptation, distribution and reproduction in any medium or format, as long as you give appropriate credit to the original author(s) and the source, provide a link to the Creative Commons licence, and indicate if changes were made. The images or other third party material in this article are included in the article's Creative Commons licence, unless indicated otherwise in a credit line to the material. If material is not included in the article's Creative Commons licence and your intended use is not permitted by statutory regulation or exceeds the permitted use, you will need to obtain permission directly from the copyright holder. To view a copy of this licence, visit http://creativecommons.org/licenses/by/4.0/.

Publisher's Note Springer Nature remains neutral with regard to jurisdictional claims in published maps and institutional affiliations.

The original article can be found online at https://doi.org/10.1007/ s11625-020-00851-5.

S. Wigboldus seerp.wigboldus@wur.nl

H. Jochemsen hjochemsen52@gmail.com

1 Wageningen Centre for Development Innovation, Wageningen University and Research, PO Box 88, 6700 AB Wageningen, The Netherlands

2 Emeritus Special Professor Christian Philosophy, CPT, Wageningen University and Research, Wageningen, The Netherlands 


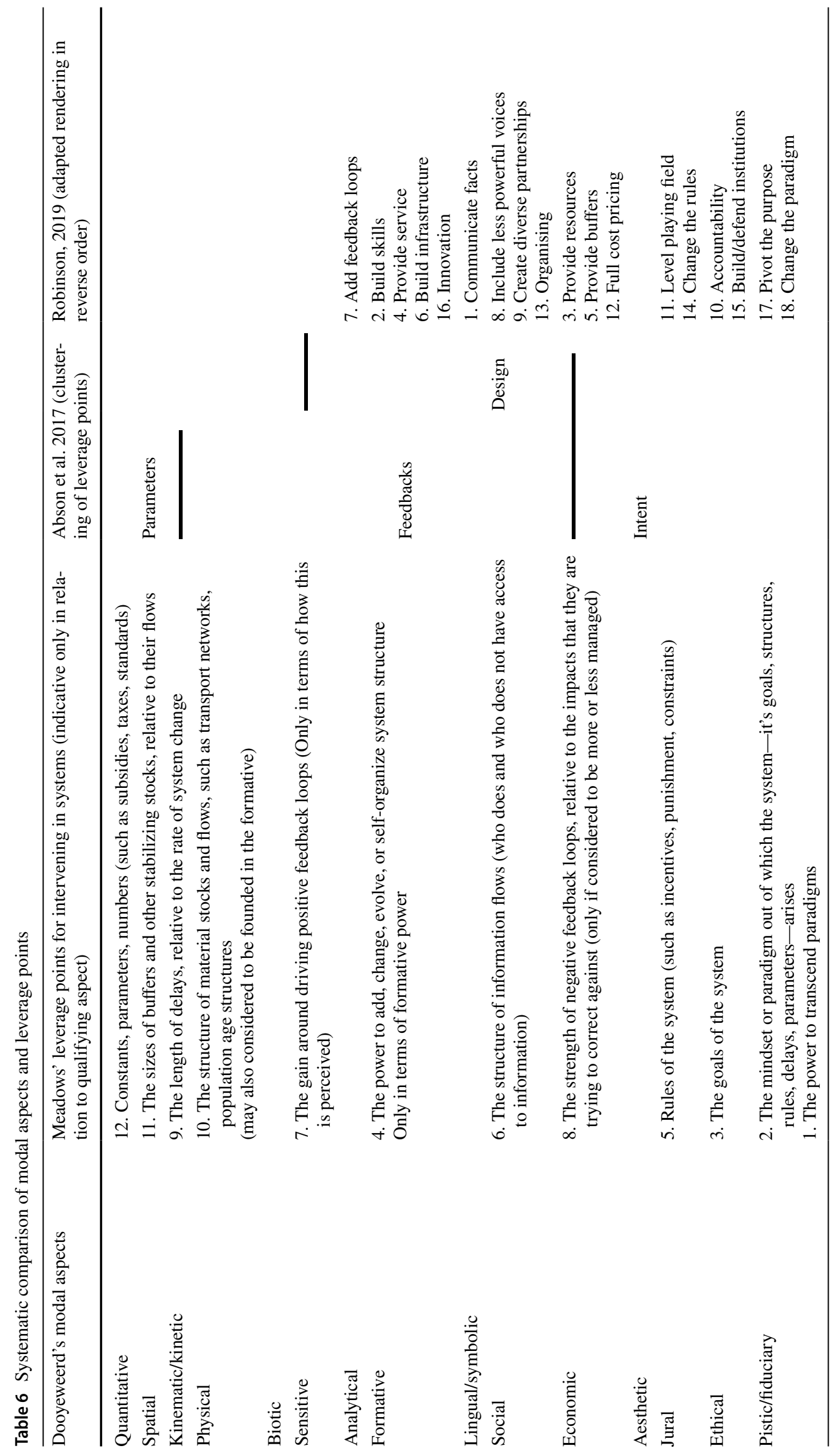




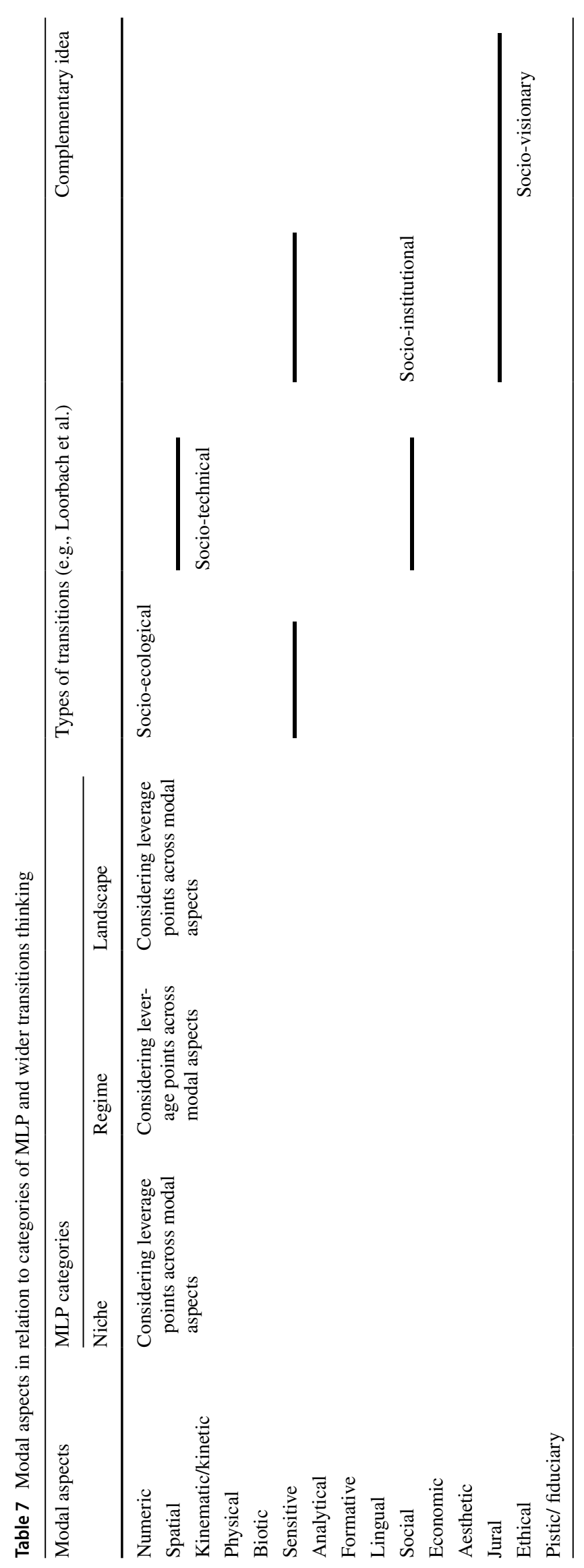

